NBER WORKING PAPER SERIES

THE GREAT RECESSION AND THE GREAT DEPRESSION

Peter Temin

Working Paper 15645

http://www.nber.org/papers/w15645

\author{
NATIONAL BUREAU OF ECONOMIC RESEARCH \\ 1050 Massachusetts Avenue \\ Cambridge, MA 02138 \\ January 2010
}

The views expressed herein are those of the author and do not necessarily reflect the views of the National Bureau of Economic Research.

NBER working papers are circulated for discussion and comment purposes. They have not been peerreviewed or been subject to the review by the NBER Board of Directors that accompanies official NBER publications.

(C) 2010 by Peter Temin. All rights reserved. Short sections of text, not to exceed two paragraphs, may be quoted without explicit permission provided that full credit, including $\odot$ notice, is given to the source. 
The Great Recession and the Great Depression

Peter Temin

NBER Working Paper No. 15645

January 2010, Revised January 2010

JEL No. E32,E65,N12

\title{
ABSTRACT
}

This paper discusses parallels between our current recession and the Great Depression for the intelligent general public. It stresses the role of economic models and ideas in public policy and argues that gold-standard mentality still holds sway today. The parallels are greatest in the generation of the crises, and they also illuminate the policy choices being made today. We have escaped a repeat of the Depression, but we appear to have lost the opportunity for significant financial reform.

\author{
Peter Temin \\ Department of Economics \\ MIT, Room E52-280A \\ 50 Memorial Drive \\ Cambridge, MA 02142-1347 \\ and NBER \\ ptemin@mit.edu
}




\section{The Great Recession and the Great Depression}

John Maynard Keynes wrote in the depths of the Great Depression that, "Practical men, who believe themselves to be quite exempt from any intellectual influence, are usually the slaves of some defunct economist." 1 This acute observation is applicable to our current Great Recession as well. In fact, the newly discredited ideas are not too different from the old, suggesting that Keynes may have overestimated the ability of people to learn from their mistakes.

I discuss the parallels between these two watersheds in recent economic history in three steps. The first and most important step is the causes of the crises and their relation to economic theory. The second step is the spread of the crises as they affected the whole world. I close with the final step, recovery - at least as far as we can see it at this point. Marx said famously that history repeats itself, "the first time as tragedy, the second as farce." ${ }^{2}$ I argue that this observation also fits our current condition.

Both of these dramatic and costly economic crises came from the interaction of economic imbalances in the world economy and the ruling ideology of financial decision makers who confronted these imbalances. The first imbalance came from the First World War. This paroxysm of violence brought the long economic expansion of the nineteenth century to a sudden end. Britain, the workshop of the prewar world, was exhausted by the struggle. America, the rising economic behemoth, was unready to take responsibility for its new role in the international economy. Germany, having unsuccessfully challenged the Anglo Saxon powers, refused to acknowledge its defeat. 
The easiest way to see the imbalance is through the international movement of capital. There were many reasons why this imbalance was allowed to grow over the postwar decade, and one of the most important was the ruling economic theory of the Gold Standard. David Hume explained in the eighteenth century how currencies valued in gold would maintain stable values relative to each other. Assume there is a shock to one country that decreases its exports. This will result in an outflow of gold according to Hume, which will lower prices in the exporting country. Lower prices then will encourage exports and decrease imports, leading to an inflow of gold. Prices will rise again, recreating the previous equilibrium. This is known among economists as the "price specie-flow mechanism."

Hume's contribution is still useful today, although we now realize how many assumptions need to be made in order for it to work as described. In particular, prices have to be determined in competitive markets and fully flexible for this simple process to operate. These assumptions have become characteristic of economic models in the years since Hume wrote, and they express a view of the economy often attributed to Adam Smith and taught in introductory economics classes. They are the starting point for many journal articles and referred to as perfectly competitive markets. When they cross the line between descriptive and normative conditions, however, they are transformed from description — which may or may not be accurate - to prescription — which in turn affects public policy.

These conditions may have been fulfilled in the eighteenth century, but they were not accurate in the postwar world of the 1920s. Central bankers thought themselves responsible for inflation and deflation in contrast to Hume's assumption of a fixed link 
between gold flows and prices. Business firms had become larger, and many product markets were no longer fully competitive. And as the size of producing units, whether mines or factories, became larger, the ability of labor markets to be fully competitive diminished also. When an employer was large, individuals had little bargaining power over their wages and working conditions. If an employer was the only large employer in town, the options for workers were even more limited and the market power of the employer more obvious. Workers formed unions to present countervailing market power to the employers, and wage bargaining and strikes supplanted the individual wage negotiations implicit in Hume's and Smith's analyses.

Nevertheless, policy makers after the Great War could think of no better way to reorganize the international economy than to restore the Gold Standard, that is, to fix one price (the exchange rate) while assuming all others were flexible. Freezing exchange rates in this fashion reduced the ability of countries to adapt to new conditions, but it was deemed preferable to the anticipated chaos of alternative arrangements. The attempt to reduce prices in England to sustain the value of Sterling resulted in a general strike, showing both how inaccurate the underlying assumptions were and the strength of economic policy based on these assumptions.

The United States took over the position of leading international lender in this context and exported massive amounts of capital to Germany in the 1920s. The loans ostensibly were to help Germany maintain the gold value of its currency, and they enabled Weimar Germany to both pay reparations owed to the victors in the Great War and have a consumption boom. Higher prices after the war also put strain on gold currencies, and England and Germany struggled as a result while economists in the 
United States proclaimed the advent of a new economy in which stability and prosperity would continue indefinitely. Hindsight suggests that these conditions were not sustainable and the questions were not how to enjoy the new economy but rather how to get a soft rather than a hard landing from the high-flying results of the previous shocks.

Economic troubles appeared in Germany and the United States in the late 1920s. Germany's consumption growth produced a boom in municipal expenditures that began to fizzle; the United States had booms in both housing and stocks that ended badly. Recessions spread from these countries to others. International trade decreased, but prices could not fall rapidly enough to equilibrate markets in the fashion Hume described. Prices were sticky, and unemployment rather than deflation was the result of a lack of foreign reserves. When all countries found their exports falling, the processes of deflation and depression chased a moving target. ${ }^{3}$

A similar international imbalance developed after the end of the Cold War, with the countries reversed. Instead of being the new world lender, the United States became the new world borrower. And a "loser" in the cold war, China, developed into the primary lender to the U.S. Even without the benefit of hindsight, economists knew that this imbalance was unsustainable and asked if there would be a soft or hard landing. As the inflow of capital to Weimar Germany had fueled expansion, the inflow of Asian capital financed a consumption boom in the United States that developed into a housing boom.

This global imbalance was apparent, and economists wondered if it would cause a crisis. The United States is no longer on the Gold Standard, and the value of the dollar can change freely from day to day. The debate was whether there would be a smooth 
decline in the value of the dollar after the fashion of the price specie-flow mechanism or an abrupt fall. These worries were misplaced; the crisis in the interwar years was precipitated by short-run booms and busts, even though the international imbalance created conditions for it. One such boom in the 1920s was in housing expenditures. It was only a minor player in the drama of the Great Depression, but it had a starring role in our current crisis.

The housing boom flourished in recent years, nourished by the availability of Chinese capital and the ruling economic theory of the Washington Consensus. This term indicated a set of economic policies that ranged from stable exchange rates and responsible fiscal policies to deregulation and privatization. ${ }^{4}$ It was an adaptation of the Gold Standard to current conditions, stipulating stable instead of fixed exchange rates to avoid the rigidities of the Gold Standard that were so harmful in the 1930s. Other requirements spelled out the conditions assumed under the Gold Standard in the era of large governments that followed the Great Depression and the Second World War. The government should stay out of the way so that private finance and industry could prosper in this theory; competition would ensure continued growth and prosperity. Like the Gold Standard, the Washington Consensus was based on the enlightenment ideas of Hume and Smith and promulgated as a way to organize the postwar world. It was the economic component of the New World Order that the first President Bush was looking for.

More explicitly than the Gold Standard mentality, the Washington Consensus spelled out the conditions needed to maintain stable exchange rates. It acknowledged that most economies in the later twentieth century did not resemble the eighteenth century conditions analyzed by Hume and Smith, and it argued that policies designed to recreate 
these earlier conditions would lead to economic growth and prosperity. Using familiar theories of competition and flexible prices, the underlying theory showed how the competitive process of allocating resources in individual markets would generate stable conditions for society as a whole.

Banks and associated businesses in the United States extended the underlying reasoning to the creation of new assets known collectively as derivatives. The Washington Consensus as a whole was a way to reduce risk, and derivatives were a way to allocate risks to those investors who wanted to take it on. Just as banks can hold fractional reserves on the assumption that people draw on their deposits randomly and independently, these innovators reasoned that home owners default on mortgages randomly and independently. Derivatives are a way to benefit from the fact that only a few homeowners default in any given time, so that most mortgages are safe. Combining mortgages into "tranches," banks could separate the safe part of mortgages from the risky parts without knowing which mortgages would be defaulted — just as banks do not know which deposits will be withdrawn but can safely assume that only a fraction will be withdrawn at any given time.

Based on the ability to sell mortgages to the creators of derivatives, mortgage brokers expanded, encouraged home ownership and promoted the Ownership Society of the second President Bush. But when the resulting housing boom burst and many mortgages failed, the assumption that defaults occurred randomly and independently turned out to be false. Derivatives were much more risky than they had appeared to be, and the separation of risky and safe assets was not valid. ${ }^{5}$ Investors refused to buy any of 
them, and credit markets seized up. Countries that had adopted the policies of the Washington Consensus found themselves in a world-wide financial crisis.

The Great Depression and the Great Depression thus were both caused by policies deriving from nostalgia for the world of the Enlightenment. Drawing on theories from the eighteenth century, hard-headed policy makers either assumed or tried to recreate the idealized conditions of Hume and Smith. These policy makers ignored both the growth of economies of scale in modern economies and the work of behavioral economists who have shown that people do not behave as homo economicus. The results of their efforts in the 1920s and in recent decades was to produce the new economy of the earlier period and the goldilocks economy of the later one that turned into booms and busts. Was it inevitable that these economic expansions would end badly? Minsky said it was, that people become more complacent with prosperity and willing to take on risks they often know are highly suspect. ${ }^{6}$ Reinhart and Rogoff more recently used historical evidence to agree that booms typically precede financial crises, just as pride goes before a fall. ${ }^{7}$

More formally, people in both expansions miscalculated the risks they faced. Their models were based on shocks to individual countries or homeowners; there was no allowance for collective actions. The Gold Standard model explained how to deal with a shock to an individual country, implicitly assuming that other countries were immune to whatever disturbance affected this individual country. The interaction between these two quite different countries led back to stability, but a collective shock to lots of economies was not considered. The model behind the Washington Consensus similarly considered individual risks. Derivatives were valued as if the underlying risk of mortgage foreclosure was the result of random and independent shocks to individual homeowners. 
As in the Gold Standard, no consideration was given to collective shocks. As long as house prices continued to rise, this assumption appeared fine. Random homeowners got into trouble and defaulted on their mortgages, and the randomness of defaults enabled derivative designers to reduce the risk to any security by diversification, that is, combining many mortgages the same way a bank combines many bank deposits. When the housing boom ended and house prices fell, however, many homeowners began to default, and the risk that was supposed to be diversified away was now present in derivatives previously thought to be risk free. No investor knew which derivative was more at risk, and the prices of all derivatives fell. Some prices fell so rapidly that there were no buyers at all for them. Financial markets froze in September 2008.

The second step of this comparison is the spread of the crisis. Countries in the early 1930s were pursuing a moving target as they all contracted in an effort to deal with what looked to each of them as budget and current-account deficits. The result was a series of currency crises in the summer and fall of 1931 that turned a bad recession into the Great Depression. The German mark collapsed when the chancellor put domestic politics ahead of sensible finance. ${ }^{8}$ The English Pound went off gold after a subsequent speculative attack. And the American Federal Reserve raised its discount rate dramatically in October 1931 to preserve the value of the dollar even though the economy was contracting at a rapid rate. The Fed kicked the American economy when it was down and drove the economy further into depression.

Many countries continued to maintain deflationary policies in the early 1930s as they tried to hold onto the Gold Standard or-in the case of Germany—-followed its prescriptions even after abandoning the Gold Standard. Some countries followed 
England off gold and created room for expansive policies, but they were not large or expansive enough to stimulate recovery in other countries still in thrall to gold. It has become common to attribute the continued economic decline to banking crises, but banks only failed in countries on the Gold Standard. ${ }^{9}$ As long as countries set policies to maintain the value of their currency, their banks were at risk; bank failures were a damaging part of the depression, not its cause. Governments and central bankers-not commercial banks - led the way into depression in country after country.

This process is shown well by the U.S. experience. Banks continued to fail as the government clung to the Gold Standard. The Reconstruction Finance Corporation refused to help a prominent Michigan bank holding company in early 1933 for reasons that are not clear, anticipating the failure of Lehman Brothers in 2008. States declared bank holidays, and the New York Federal Reserve Bank lost gold as investors speculated against the dollar. Roosevelt, taking office in early March 1933, immediately instituted what he called a federal bank holiday to keep the banking system from complete collapse. ${ }^{10}$

Banks and other private financial institutions were the center of the financial panic that initiated the Great Recession. Banks and other financial institutions had accumulated large portfolios of mortgage-backed securities, where mortgages were combined and then separated —at least in theory—into securities of differing risks. When the housing boom ended in 2006 and 2007, home owners began to default on mortgages at an increasing rate. These defaults were not the random defaults assumed in the construction of mortgage-based securities, and investors could no longer tell the various 
derivatives apart. Efficiency-promoting securities were transformed into toxic assets as it became progressively harder to sell them.

Tightness in American and European financial markets caused by the inability to sell these toxic assets was apparent in the summer of 2007. Pressure continued during the fall, and the Fed lowered its discount rate by more than a percentage point between September and the following January. (The National Bureau of Economic Research later concluded that a recession had started in December 2007.) Fed Chairman Bernanke, Treasury Secretary Paulson, and President of the New York Fed Geithner rescued the New York investment house of Bear Stearns at the point of collapse with Fed funds and purchase by another investment house in March 2008, and they took over the two quasigovernmental mortgage brokers, Fannie Mae and Freddie Mac, in August. Even at this late date, the Fed and other public figures argued that the pressure was largely limited to the housing sector and that the measures taken so far were sufficient to maintain financial health.

Bernanke and Paulson asserted after the fact that they tried to get Congress to take action to forestall a crisis in the summer of 2008. This effort proved futile for several reasons. The financial leaders were making reassuring statements to the public at the same time they were appealing to Congress. This mixed message did not lend persuasiveness to any arguments they presented. In addition, Congress was not convinced that the financial system was on the verge of a meltdown and was reluctant to act outside of an emergency. This probably is a general problem: it is hard to prepare for a hypothetical crisis without having evidence that it is about to emerge. And of course if palliative action forestalls the putative crisis, people ask what all the pressure was about. 
Congress is a large and unwieldy body; all these complexities precluded preventive action in the summer of 2008 .

In September another investment house, Lehman Brothers, found itself unable to borrow. It tried selling assets to pay its obligations but could not sell its toxic assets and fell short of its needs. Creditors wanted to be paid and investors wanted to sell Lehman's stock. Although an investment rather than a commercial bank, Lehman was in a process that resembled nothing so much as an old-fashioned banking panic. Bernanke, Paulson, and Geithner could not repeat their rescue of Bear Stearns and allowed Lehman to fail on September 15, 2008. None of these articulate policy makers was able to tell a coherent story after the fact why they had not avoided Lehman's bankruptcy. This reprised the government confusion that led Michigan banks to fail in early 1933, precipitating the bank holiday.

The financial triumvirate had tried to find a buyer for Lehman as they had done for Bear Stearns but were unable to do so. They apparently reverted to the Gold Standard mentality as expressed in the free-market ideology of the Washington Consensus; Lehman had taken large risks and now had to pay the penalty for losing too many bets. But hard on the heels of Lehman came AIG. Not even an investment bank, this multinational insurance company also had taken too many bets on what were now toxic assets and was about to collapse. The epidemic had escaped the mortgage market and infected the whole financial system. We were in what Mishkin, a member of the Fed's Board of Governors had called an "adverse feedback loop" almost a year earlier. ${ }^{11}$ One failure induced another; we were in a world-wide financial panic. 
Paulson, et al., threw in the towel and nationalized AIG. Their commitment to the free market had lasted one day; Congressman Barney Frank suggested we call it Free Market Day! ${ }^{12}$ But while the sale of Bear Stearns had calmed the financial markets, the nationalization of AIG — coming on the heels of Lehman's bankruptcy—only confused the market. The government had restated its ideals and then abandoned them in the twinkling of an eye. Investors could not predict what would come next. ${ }^{13}$

Credit markets that were barely functioning seized up completely. No one knew what the government policy was or if anyone was insured; no one wanted to purchase toxic assets. Economic activity came to a sudden halt. International trade fell off a cliff. The brief reassertion of faith in the free market in 2008 was as counter productive as fidelity to the Gold Standard had been in 1931. Now as then, the United States dragged the world down with it—faster than fifty years earlier. ${ }^{14}$

Fortunately, we are now in a great recession, not a repeat of the Great Depression. We have 10 percent unemployment and unemployment insurance instead of 20 percent without a safety net. The primary reason for this divergence is the vagary of the American political cycle. Voters had to wait three years after the Great Depression began and a full year after the Fed turned a recession into a depression to vote on public policy, but voters in 2008 had this opportunity just months after the financial crisis began. The similarity between now and then is that it took a new group of leaders to change policy. The Obama administration has many holdovers, and Obama has reappointed Bernanke as Fed Chairman, but there is no doubt that the theories underlying the policy are now different than they were in the last administration. One difference between now and then 
is that — since this is only a recession— Obama does not have the opportunity for reform that Roosevelt did.

Roosevelt opened most banks quickly after their holiday, and he took the United States off gold a month later. He introduced the National Industrial Recovery Act (NILR) and the Agricultural Adjustment Act (AAA), pillars of the New Deal, shortly thereafter. This complex of actions signaled a clear new direction in government policy, what economists call a new policy regime. Investment rose and consumption began to recover; the long economic decline had ended. ${ }^{15}$

It has become common to blame the continuation of high unemployment in the 1930s on high wages created by the NIRA and subsequent growth of unions. This is wrong for several reasons. Economic growth was exceedingly rapid during Roosevelt's first term. It probably could not have been faster due to bottlenecks in the supply of raw materials and production. Faster growth, even if possible, probably would have led to inflation despite the high unemployment. ${ }^{16}$ In fact, the recovery was so fast that both the Fed and the government decided to reverse policy and rein in demand by both monetary and fiscal policies. The result was the recession of 1937 which increased unemployment and delayed the return to full employment for several more years. Labor's gains in the Depression were not the cause of its continuation.

The growth of unions was only one of the results of the New Deal, Roosevelt's blizzard of reforms to the prostrate economy. Not all of these reforms were consistent with each other, and not all of them lasted more than a few years. The enduring parts of the New Deal however changed the economy in many ways. Labor and tax reforms preserved a stable income distribution in the economic expansion that followed the 
Second World War. Creation of the FDA led to the expansion of the pharmaceutical industry that extended life for many people, and Social Security made the lives of older people vastly more pleasant.

Reforms to the financial system led to a half-century free of financial crises. The Federal Deposit Insurance Corporation (FDIC) freed most people from worry about the safety of their bank accounts. This insurance was complemented by bank regulation to substitute for critical investors and depositors. Commercial and investment banks were separated from each other in the Glass-Steagall Act. The Federal Reserve System was restructured to make its central office more powerful, and the Security Exchange Commission (SEC) was created to regulate financial investments. Banking became a boring industry, and more people invested safely in the stock market. There was not a lot of excitement in the financial markets, and the economy grew rapidly and consistently after the war.

Nothing lasts forever, and prosperity generated a desire for more independent financial dealings. Economic turmoil in the 1970s hastened the transition, and the Washington Consensus arose in the 1980s. The Glass-Steagall Act was repealed, and the SEC became more relaxed. Americans urged the rest of the world to follow suit and deregulate both domestic and foreign capital movements. The distribution of income widened, the size of the financial sector rose, and there began to be a string of small-scale (at least to the United States) financial crises.

This foreshadowing of our current problems was not seen as such at the time, even the failures of Long Term Capital Markets (LTCM) in 1998 and of Enron in 2001. Most of the crises, like the Asian crises of 1997 (which spread to Russia, bringing down 
LTCM), were seen as problems of less developed countries, not mature economies like the United States. Economists and politicians alike pushed for less regulation at home and deregulation abroad. They particularly sought to deregulate the international flow of capital and hailed the Washington Consensus as the way forward for all countries, developing and developed. They were like Irving Fisher, a great economist of the early $20^{\text {th }}$ century who believed his models too much and predicted continued prosperity just before the Great Depression. ${ }^{17}$

Even Bernanke, chairman of the Federal Reserve and student of the Great Depression did not see chaos ahead during most of 2008. Bernanke, to his credit, realized what was happening by the start of 2009. He resolved not let the Fed duplicate its mistakes of the early 1930s, standing by as banks failed and supporting the gold standard instead of the domestic economy. He pulled all the strings—-some of them on the outer edge of his authority - to loosen monetary policy and encourage economic activity. It was a bravura performance, but monetary policy had lost its effectiveness as banks ran for safety even after the financial panic subsided. The banks used the Fed's services to rebuild their depleted reserves as the value of toxic assets went to zero, and they loaned only to the safest of customers. ${ }^{18}$

Obama, even before he took office, urged Congress to pass a stimulus bill—to create a fiscal expansion in addition to the hobbled monetary expansion. Republican congressmen made him divert part of the stimulus to tax cuts, which went into savings as people - like banks - tried to build up their depleted reserves, limiting the size of the stimulus. This fidelity to the Washington Consensus reduced Obama's ability to moderate the effects of the recession on ordinary people. 
Expansive monetary and fiscal policies were effective enough to keep us from a repetition of the Great Depression, and support for reforms on the order of the New Deal ebbed. Obama had campaigned on a program of bipartisan cooperation, and he tried to bring Republicans along with his policies. They had not abandoned their belief in the Washington Consensus, and banks - newly prosperous again due to government bailouts - resisted increased regulation. Obama put extending health care to all Americans before reforming the financial system, and the window for the latter appears to have closed.

There are two lessons to be drawn from this comparison. The first is that the open American economy is prone to collapse every once and a while. Favorable conditionsthe New Deal and a vigorous post-war expansion—can eliminate "great" economic contractions for a generation or so, but American exuberance appears to chafe under these conditions. As the memory of past economic difficulties fades, economic and political pressure for change rises to the fore. International economic imbalances are condoned until they have to be corrected, often painfully.

The second lesson is that there are strong pressures for unregulated capitalism that only abate in the face of sharp economic downturns like the Great Depression. We avoided another Great Depression by luck—-the election cycle—and skill. Marx was correct when he argued that tragic history repeats itself as farce: we now have the oxymoronic Great Recession after all the fears of Great Depression II. Keynes was right too; discredited economic theories — and the Gold Standard mentality—will continue to dominate the actions of even "practical" men and women. ${ }^{19}$ Recent policy initiatives appear to have done little to reduce the underlying risk of another financial crisis. 


\section{Notes}

${ }^{1}$ John Maynard Keynes, The General Theory of Employment, Income and Money (New York: Harcourt, Brace, 1936), Chap. 24, "Concluding Notes."

${ }^{2}$ Karl Marx, The Eighteenth Brumaire of Louis Bonaparte (New York, 1852), p. 1.

${ }^{3}$ Peter Temin, Lessons from the Great Depression (Cambridge, MA: MIT Press, 1989); Barry Eichengreen, Golden Fetters: The Gold Standard and the Great Depression, 1919-1939 (New York: Oxford University Press, 1992).

${ }^{4}$ Williamson, John, "What Washington Means by Policy Reform," in John Williamson (ed.), Latin American Adjustment: How Much has Happened? (Washington: Institute for International Economics, 1990).

${ }^{5}$ Peter Temin, "Real Business Cycle Views of the Great Depression and Recent Events: A Review of Timothy J. Kehoe and Edward C Prescott's Great Depressions of the Twentieth Century," Journal of Economic Literature, 46 (September 2008), 669-84; “Corrigendum,” Journal of Economic Literature, 47 (March 2009), 3.

${ }^{6}$ Hyman P. Minsky, Can “It” Happen Again? Essays on Instability and Finance (Armonk, NY: M. E. Sharpe, 1982).

${ }^{7}$ Carmen M. Reinhart and Kenneth S. Rogoff, This Time Is Different: Eight Centuries of Financial Folly (Princeton: Princeton University Press, 2009).

${ }^{8}$ Thomas Ferguson and Peter Temin, "Made in Germany: The German Currency Crisis of 1931," Research in Economic History, 21 (2003), 1-53; Peter Temin, "The German Crisis of 1931: Evidence and Tradition," Cliometrica, 2 (April 2008), 5-17.

${ }^{9}$ Grossman, Richard S. 1994, "The Shoe That Didn't Drop: Explaining Banking Stability During the Great Depression.” Journal of Economic History, 54 (September 1994): 654-82.

${ }^{10}$ Barrie A. Wigmore, The Crash and Its Aftermath: A History of Securities Markets in the United States, 1929-33 (Westport, CT: Greenwood Press, 1985), pp. 433-47.

${ }^{11}$ Frederic S. Mishkin, Speech at the Risk USA Conference, New York, NY, November 5, 2007. www.federalreserve.gov/newsevents/speech/mishkin20071105a.htm.

${ }^{12}$ David Wessel, In Fed We Trust: Ben Bernanke's War on the Great Panic (New York: Crown Business, 2009), p. 26.

13 Thomas Ferguson and Robert Johnson, “Too Big to Bail: The 'Paulson Put,' Presidential Politics, and the Global Financial Meltdown," Parts 1 and 2. International Journal of Political Economy, 38 (Spring 2009), 3-34, and 38 (Summer 2009), 5-45.

${ }^{14}$ Christina D. Romer, "Back from the Brink," speech to the Federal Reserve Bank of Chicago, September 24, 2009. http://www.whitehouse.gov/assets/documents/Back_from_the_Brink2.pdf.

${ }^{15}$ Peter Temin and Barrie A. Wigmore, "The End of One Big Deflation," Explorations in Economic History, (October 1990), pp. 483-502.

${ }^{16}$ Christina D. Romer, "Why Did Prices Rise in the 1930s?" Journal of Economic History, 59 (March 1999), 167-99.

${ }^{17}$ Irving Fisher, "Fisher Sees Stocks Permanently High,” New York Times, October 16, 1929, p. 8.

${ }^{18}$ Richard C. Koo, The Holy Grail of Macroeconomics: Lessons from Japan's Great Recession (Singapore: John Wiley (Asia), 2008).

${ }^{19}$ Paul Krugman, "How Did Economists Get It So Wrong?" New York Times, September 6, 2009;

“Misguided Monetary Mentalities,” New York Times, October 12, 2009. 